\title{
Exploring English Language Learning Policies in Iran Based on Secondary School Course Books for Learning English in Light
of Globalization and Culture
}

\author{
Soroor Sadat Farhang \\ Imam Reza International University, \\ Mashhad, Iran
}

\author{
Majid Elahi Shirvan \\ University of Bojnord, Bojnord, Iran
}

\author{
Behzad Ghonsooly \\ Ferdowsi University of Mashhad, \\ Mashhad, Iran
}

\begin{abstract}
With the globalization of English, the macro and micro cultures of the users of English around the world interact intensively. Considering these conditions, the local and global cultural interface seems an important issue which needs to be clarified in the materials and books used for learning English. Thus, the focus of this study was to explore the language learning policy of the new Iranian English course book at high schools, Prospect 1, recently published and taught for a year in Iran, in light of globalization and culture. This qualitative study was conducted through carrying out semi-structured interviews. The participants of this study were 30 teachers of Ministry of Education, who had the experience of teaching Prospect 1 for a year and they were mostly chosen from Mashhad and the rest from other cities of Khorasan province, Iran. The interview contained four main questions which were posed to the teachers. The findings of the study indicate that the language learning policy of Iran need to pay more attention to the learners' intercultural communicative competence because it mainly attempts at teaching English language focusing on the home culture in the Iranian context. The article ends with some pedagogical implications and more recommendations for developing research studies.
\end{abstract}

Keywords: globalization, culture, intercultural communicative competence, language learning policy, Prospect 1

\section{Introduction}

Globalization is a highly intricate process that has made a significant impact on the multidimensional aspects of societies at various levels, including language policies of many countries (Tsui \& Tollefson, 2007, as cited in Aouina, 2013, p. 19). To respond to the rapid changes brought about by globalization, all countries have been trying to ensure that they are adequately equipped with these two skills. At the international level, English is needed to maintain communication with the outside world for economic, social, and business relations to accelerate a country's modernization process. As Lin (2013) noted, the unprecedented spread of English as the lingua franca of international communication, coupled with globalization, has generated huge impact on language policies of non-English-speaking countries. Kachru (1992) has proven the most influential dividing English use into three categories: the Inner Circle, Outer Circle, and Expanding Circle. The model

Soroor Sadat Farhang, M.A., Imam Reza International University.

Majid Elahi Shirvan, Ph.D., English Language Department, University of Bojnord.

Behzad Ghonsooly, Ph.D., English Language Department, Ferdowsi University of Mashhad. 
distinguishes native speakers in the Inner Circle from the non-native speakers in the Outer and Expanding Circles (Mollins, 2006, p. 41). Unlike countries in the outer circle where English functions as the official or co-official language, as in India, in the expanding circle countries, English is taught as one of the foreign languages in the school curriculum for the purpose of communication with the Inner and Outer Circles. With regard to the use and status of English, countries such as Turkey, China, Iran, Japan, and so forth belong to the Expanding Circle. The major challenges posed by globalization for countries of Expanding Circle is crucial because as noted by Tsui and Tollefson (2007), the English language which functions as one of the most important meditational tools for globalization, is not their native language (as cited in Kirkgöz, 2009).

Hence learning a new language should accompany learning its culture and as Sun (2013) confirmed, since the communication between people who are from different cultural background is more and more prevalent in the globalization era, various misunderstandings and conflicts might happen (p. 2246). Therefore, acquiring intercultural communicative competence and the importance of it was emphasized by many scholars (Freeman, 2002). Through this, as Sun (2013) explained, people can learn and adapt to the different cultural habits, and can deal with the cultural differences between the two communicating parties creatively. People who have the ability of intercultural communicative competence, not only master the two or more cultural knowledge, but more important they experience the process of cultural harmony (p. 2247). Hence, the question of how to respond to challenges like this which is posed by globalization on language policy has been on the agenda of many countries. However, "language policies all over the world have responded in different ways and on different levels to globalization and to the spread of English as the main language recognized to be the language of globalization" (Aouina, 2013, p. 31).

Consequently, many countries in Asia, for example, Iran, where English has been used as a foreign language over decades, have adopted teaching and learning of English in their education policies in response to the realities of a more globally connected world. Recently, there has been a shift to these junior high school English textbooks and a new series of course books, called Prospect, has been developed. Thus, the need for exploring culture within the agendas for English language learning in Prospect series is felt. The extent to which these official books provide Iranian English language learners to survive in a global village, bring with them their own cultural backgrounds and experiences, and cope with the cultural differences needs more exploration. In addition, based on the fact that the world interactions, economics, marketing, and so forth, have progressed remarkably these days, the latent policies regarding constructing an Iranian Identity or a global Identity for Iranian learners of English needs systematic investigation.

Therefore, this study primarily aimed at investigating and exploring the policy of English language latent in Prospect series through interviews with Iranian English language teachers who have taught English with these books.

\section{Review of Literature}

\section{Ecology of Language}

According to Phillipson and Kangas (1996), language ecology has different range of meanings these days. It is used simply as a reference to "context" or "language environment" by many researchers to describe language-related issues existed in (micro or macro) sociolinguistic, educational, economic, or political settings rather than de-contextualized (p. 1). Wendel (2005) as cited in Wiertlewska (2011) asserted that the ecological approach to language that it takes into account the complicated network of relations occurring between 
environment, languages, and those who are speaking these languages (p. 142). Language ecology is a widespread approach within such fields as second language acquisition (SLA), bi- and multilingualism and language diversity, death, and revitalization (Crystal, 2000, as cited in Kramsch \& Vork Steffensen, 2008). For Kramsch and Vork Steffensen, a significant word in either in linguistics or in life sciences, is holism. A holistic approach to linguistics suggests that language is not studied as an isolated, self-contained system, but rather in its natural surroundings. In other words, we study it in relation to the personal, situational, cultural, and societal elements that collectively form the production and language change or evolution, ontogenetically as well as phylogenetically. Linguistic holism leads to a number of methodological considerations, shared by great number of ecolinguists (p. 18). The summary of these points are as follows:

According to Baker (2011), as cited in Creese, Martin, and Hornberger (2010), in the realm of ecology, those which are the most diverse are the strongest. Diversity is straightforwardly related to stability; variety is vital for long-term survival. We as human beings have succeeded on this planet as a result of our capability to adapt to various types of significant environments over thousands of years. This ability is originated from diversity. Therefore, language and cultural diversity maximizes chances of human success and adaptability (p. 3). Creese, Martin, and Hornberger (2010) explicated that Bicultural diversity ( = biodiversity + linguistic diversity + cultural diversity) is vital for long-term planetary survival because it reinforces creativity and adaptability and thus stability (p. 11). Thus, the paradigm of ecology of language involves building on linguistic diversity worldwide, promoting multilingualism and foreign language learning, and granting linguistic human rights to speakers of all languages (Phillipson \& Skutnabb-Kangas, 1996, as cited in Creese, Martin, \& Hornberger, 2010, p. 14).

The spread of English is associated with linguistic imperialism and genocide, subtractive bilingualism, cultural homogenization, capitalism, and so on. By contrast, the ecological thrust means multilingualism and diversity, communicative equality, economic democratization, resource redistribution, and so on. Skutnabb-Kangas and Phillipson argue that a balanced linguistic ecology does not allow some languages to spread at the cost of others (Creese, Martin, \& Hornberger, 2010, p. 20).

\section{Culture}

When language is used in contexts of communication, it is bound up with culture in multiple and complex ways. According to Collins English Dictionary (1991, 1994, 1998, 2000, 2003) as cited in Tengku Mahadi and Moghaddas Jafari (2012),

From the sociological perspective, culture is the total of the inherited and innate ideas, attitudes, beliefs, values and knowledge, comprising or forming the shared foundations of social action. Likewise, from the anthropological and ethnological senses, culture encompasses the total range of activities and ideas of a specific group of people with common and shared tradition. (p. 231)

Nieto (2010) pointed out that culture is not separated from human beings. That is, cultures are not moribund behaviors, static relics, or lifeless values. Indeed culture is changing and dynamic. They are even changing within their native contexts due to the political, social, and other variation in the immediate milieu. Such change happens even more, when people of different backgrounds come in contact with one another. The reality is cultural change is not simply a unilateral process but it is always hybrid (p. 137). "Each society has its own special culture either simple or complex. If culture is taken seriously, it seems that people require not only sufficient food but also well-cooked food" (Mahadi \& Jafari, 2012, p. 231). Sapir (1971) defined culture as well 
as "a system of behaviors and modes that depend on unconsciousness" (p. 21). It can be inferred from the definitions that language is deeply implicated with culture and an important part of it. Moreover, culture has a direct effect on language. In other words, "language is the symbolic presentation of a culture" (Mahadi \& Jafari, 2012, p. 234).

Stern (1992, p. 206) as cited in Corbett (2003) noted that the cultural component has remained difficult to accommodate in practice. In fact, cultural content was often stripped from learning materials (p. 1). Corbett (2003) maintained that throughout the 1970s and much of the 1980s, materials and syllabus design were gained by needs analysis, and culture was subordinated to performance objectives. Nevertheless, more recently, there have been conscious attempts to combine culture into the communicative curriculum. While acknowledging the conspicuous importance of language as a way of communicating information, upholders of an intercultural approach also underlie its social functions; for example, the ways in which language is used by speakers and writers to negotiate their place in social groups and hierarchies. It has long been patent that the ways in which these negotiations happen vary from community to community (p. 2). Valdes (1990) as cited in Corbett (2003) explicated that any method of language teaching and learning is ineluctably cultural,

From the first day of the beginning class, culture is at the forefront. Whatever approach, method or technique is used, greetings are usually first on the agenda. How can any teacher fail to see the cultural nature of the way people greet each other in any place in any language? The differences made in formal greetings, casual greetings, in greetings of young to old and vice versa, of employee to employer, in who shakes hands, bows, or touches the forehead, who may be called by first names, etc. are certainly not universal and serve as an excellent introduction to the culture of the people who speak the language, as well as to the language itself. (p. 33)

Moreover, in these classes the learners face another culture more directly. By reading another culture, they get more acquainted with their own home culture. Home culture and the foreign culture can have dialogue in class, helping the learners to create or maintain identities. (Pishghadam, 2011, p. 11)

\section{Intercultural Communicative Competence}

Byram (1992) commented that teaching foreign languages in secondary schools has become a trend as if students were supposed to become tourists and holidaymakers in the foreign country. They require the language for survival in such situations and will be given some "useful" but rather superficial information about the given country. Therefore, such information is not supposed to have impact on student's ideologies and their judgments of their identity and that of others; they are strongly suggested to believe firmly their own values and cultures and keep them (p. 11). Kramsch (2005) remarked that a fundamental part of intercultural communication is to understand strangers communication styles which require an essential step to go beyond the dichotomy of "us" versus "them". Sumner (1906) as cited in Kramsch (2005) introduced the concept of "ethnocentrism" in early last century; it refers to the fact that most people find their own culture as the "center of the universe". Frequently, this phenomenon was seen as the result of "naïve" thinking. Ethnocentrism is the result of misunderstanding of others. The way we look at others and the world is as crucial as we will spoil the usefulness and productiveness of others by our own negative attitudes. We judge them by our own life experience, not their context. One aspect of a more general ability to manage several languages and cultures is to gain knowledge of another person's language and take account of someone else's culture as well as keeping yours. This is called cross-cultural, intercultural communication. The notion of "cross-cultural" or Intercultural usually refers to the encountering of two cultures or two languages across the political boundaries of nation-states. 
Byram (1997) has produced what is to date the most fully worked-out specification of intercultural competence, which involves five so-called savoirs, that is, five formulations of the kinds of knowledge and skills needed to mediate between cultures. These are specified as follows: (1) knowledge of self and other, of how interaction occurs, of the relation-ship of the individual to society; (2) knowing how to interpret and relate information; (3) knowing how to engage with the political consequences of education, being critically aware of cultural behaviors; (4) knowing how to discover cultural information; and (5) knowing how to be: how to relativize oneself and value the attitudes and beliefs of the other (Corbett, 2003, p. 42).

This set of savoirs incorporates and transforms the goals of communicative curricula, even those in which culture found some kind of place. In an intercultural curriculum, the learner is still expected to aggregate facts about the target culture and know something of how people from that specific culture might be expected to behave. Corbett (2003) stated that because culture is indirectly built into ELT (English Language Teaching) courses, learners will automatically get cultural knowledge. These arguments consider that there will always be a conscious teacher ready to illuminate cultural points which are difficult to understand for the learner, or that the learner's experience of the culture will not extend beyond the bounds of any one course. However, by cheering learners to be active analysts and interpreters of culture (including their own), we contribute to their improvement in this way to become an independent intercultural analysis and interpretation in different situations where they might otherwise be at a loss, and where there is no leading (p. 45). Corbett (2003) continued that a language course regarding "culture", then, extends its scope from an attention on improving the "four skills" of reading, writing, listening, and speaking, in order to help learners gain cultural skills, such as strategies for the systematic observation of behavioral patterns. The final end of an intercultural approach to language education is not so much "native speaker competence" but rather an intercultural communicative competence (p. 13). Even the trace of intercultural communicative competence is discussed in another vein of argument in translation studies as Ricoeur illustrates.

\section{Deficit Theory}

The relationship between language and social class is both theoretically and empirically a key issue in critical discourse studies and sociolinguistic research. In the1970s, the British sociologist, Basil Bernstein conducted a study of working- and middle-class children. He argued for the existence of two quite distinct varieties of language use in society: the elaborated code and the restricted code, which he claimed to account for the relatively poor performance of working-class pupils in language-based subjects while they were scoring just well as their middle-class peers in mathematical subjects.

According to Atherton (2002), the essence of the distinction between the two codes is in what language is suited for. The restricted code works better than the elaborated code in situations where there is a great deal of shared and taken-for-granted knowledge in the group of speakers. Restricted codes are context dependent and particularistic, whereas elaborated codes are context independent and universalistic. Bernstein argued that restricted codes are not deficient, but rather are functionally related to the social division of labour, where context dependent language is necessary in the context of production. The elaborated code spells everything out, not because it is better, but because it is necessary so that everyone can understand it. It has to elaborate because the circumstances do not allow the speaker to condense. The elaborated code works well in situations where there is no prior or shared understanding and knowledge, where more thorough explanation is required. 
If one is saying something new to someone $\mathrm{s} / \mathrm{he}$ has never met before, $\mathrm{s} /$ he would most certainly communicate it in the elaborated code.

\section{Linguistic Imperialism}

According to Macmillan Dictionary's definition, the belief or assumption that everyone should speak English because it is the main means of international communication is called linguistic imperialism. Ljungdahl (2004) asserted that linguistic imperialism is connected to the universal expansion of the English language, especially where English becomes dominant at the expense of indigenous languages. The spread of English may cause other languages to gain less attention, because English can be a gatekeeper to education, employment, job opportunities and popular culture (p. 1).

Based on Phillipson (2009), different literature on English includes perfect portrayals of the history of how and why the language spread and many description of its diversity in different parts of the world. When analyzing English worldwide, the most important pint is whose interests English serves (p. 28). Hung (2009) stated that Robert Phillipson in his influential book Linguistic Imperialism (1992), popularized the phrase linguistic imperialism. He spoke of the "hegemony" of English and remarked that the advance of English has invariably been at the expense of other languages. This point of view was echoed by others and it was debatable among scholars for several years (p. 4). Therefore, linguistic imperialism is "the dominance of English is asserted and maintained by the establishment and continuous reconstitution of structural and cultural inequalities between English and other languages (Phillipson, 2009, p. 47).

Kramsch (2009) pointed out that the linguistic rights have been made specifically strongly with respect to the hegemonic spread of English around the globe. Beyond the symbolic link frequently established between language and territorial or cultural identity, there is also another link that has more relevant to the promulgation of global ideologies through the expansion of worldwide of one language, also called Linguicism (p. 76). Linguicism has been defined as "ideologies, structures, and practices which are used to legitimate, effectuate, and reproduce an unequal division of power and resources (both material and unmaterial) between groups which are defined on the basis of language", as Phillipson says in his book Linguistic Imperialism, in which English linguistic imperialism is seen as a type of linguicism (Kramsch, 2009, p. 77).

Global migrations, the emergence of the internet and the global expansion of English have raised concerns about the appropriateness of imposing one NS model for all (Kramsch \& Vork Steffensen, 2008, p. 20). The terms "native/non-native" are offensive and hierarchical in that they take the native as the norm, and define the other negatively in relation to this norm. Thus are hierarchies internalized subconsciously and they serve hegemonic purposes (Phillipson, 2009, p. 40).

Kramsch (2009) believed that much of the discussion surrounding the native speaker has been focused around two concepts: authenticity and appropriateness. The willingness to learn the language of others is mostly accompanied with a desire to behave and think like them, in order to ultimately be recognized and validated by them. The notion of authenticity and appropriateness in language learning has been put into question by two factors: first, the diversity of authenticities within a national society, depending on such contextual variables as age, social status, gender, ethnicity, race; what is authentic in one context might be not authentic in another; second, the undesirability of imposing on learners a notion of authenticity that might downplay their own authentic selves as learners. Thus cultural appropriateness may need to be replaced by the concept of appropriation, whereby learners make a foreign language and culture their own by adapting it to 
their own needs and interests (p. 80). According to Kaur (2014), one reason for the more favorable and positive attitudes towards NS English accents could be the deeply entrenched attachment to NS English accents as most textbooks and materials are NS-centric (p. 221)

The "ecocultural" model proposed by Quirk (1988) and advocated by Brutt-Grifler (1998), is thus a counter argument to linguistic imperialism. Depoliticizing the spread of English or advocating its neutral "spread" has given rise to the literature surrounding "World Englishes", English as an International Language (EIL), and English as a Lingua Franca (ELF). These three common terms have different emphases, with World Englishes (Kachru, 1986; Bhatt, 2008) focusing and celebrating the new roots of English and local appropriations of the language. (Jamshidifar, 2011, p. 42)

\section{English Globalization}

Crystal (2003) as cited in Sifakis (2004) explained about peculiarity of English that because English language is basically the first choice to establish a communication between various non-native speakers (NNS), it is distinguished as a natural language (p. 240). According to Kaur (2013), English has been given rise and validity as an International Language or as a Lingua Franca, by the growth of NNSs and change of roles and functions of English all over the world (p. 215). Crystal (1997), as cited in Jamshidfar (2011), stated that English as an International Language (EIL) underscores the need to move away from native speaker, native speaker culture, and an internationally sensitive pedagogy of English language teaching. English as a Lingua Franca (ELF) pays more heed to the global need for a language of global communication. However, these terms have their various focuses; they all appear to fall into an apolitical group of English as a Global Language (p. 42).

Jenkins (2009) maintained that the phenomenon of English as a Lingua Franca (ELF) has turned to the moot discussion during the past few years. By use of "English as a Lingua Franca", a specific communication context is referred: Speakers from various linguacultural backgrounds are using English language as a lingua franca, the usual language of choice (p. 200). ELF is defined as a "world language whose speakers communicate mainly with other non-native speakers, often from different L1s than their own" (Jenkins, 2006, as cited in Kaur, 2013, p. 215). Jenkins (2007) could prove the myths surrounding ELF, many of which are tied to the existence of a standard English, wrong.

Standard English is typically defined as the English of a native speaker, usually containing American or British pronunciation and idioms, and consistent with a native speaker's fluency. Holding this select variety of English as the standard frequently breeds prejudice and language insecurity, and ELF forms are often considered "incorrect" or to contain "transfer errors" from the L1 (Jenkins, 2007, p. 120).

\section{Globalization, Culture, and ELT Materials: A Focus on China}

In this paper, Xu (2013) analyzed ELT textbook materials for secondary schools in China. The analytical framework was based on current EIL principles and criteria for ELT materials (Sharifian, 2009; Mckay, 2012; Matsuda, 2012) and the Chinese secondary school English textbooks have been collected as data. Xu (2013) stated that earlier texts for learning English were either localized or imported texts, e.g., The Aesop's Fables and The Million Pound Note. In the 1980s and 1990s, the English textbooks that were commonly used in China mainly included texts written in the so-called "standard" English expressing the cultural values of Americans or British. Since the beginning of the century, Chinese ELT materials for secondary schools have been developed to incorporate both global and local Chinese cultures, specifically designed for Chinese learners of English. This new dimension in ELT material development was aligned with Chinese conceptualizations of 
globalization, culture and the changing profile of the English language, and the emerging Chinese variety of English. Major research questions included whether the texts expose the Chinese secondary school English learners to diversities of English and cultures; what cultures are represented; and whether the texts help engage the Chinese students in using English, and provide opportunities for the students to associate their own Chinese cultures with other cultures. In sum, after all observations and analyses done by $\mathrm{Xu}$ (2013), he concluded that through a new series of English textbooks adopted nationwide for secondary school in china, (1) texts about cultures other than English co-exist with texts of traditional inner-circle cultures; (2) cross-cultural perspectives are represented in English textbook series; (3) multiculturalism has been incorporated into the texts; and (4) texts that help raise awareness of world Englishes and local functionalities of English are included in the textbooks.

\section{Method}

\section{Participants}

The population selected for this qualitative study was English teachers of ministry of education who had the experience of teaching Prospect 1 for a year. The number of teachers was 30, including 18 female and 12 male teachers. Teachers of different districts of Mashhad, Iran, were supposed to participate. Therefore, it was attempted to select teachers from most of Mashhad's districts, such as districts 1, 3, 4, and 6. Also some teachers from other cities of Iran such as Bojnord, Shirvan and a teacher from Khoozestan participated.

\section{Material/Instrumentation}

This research is based on Prospect 1, a newly written book which is being taught by Iranian English teachers of ministry of education. The research is carried out through interviews.

\section{Procedure}

\section{Data Collection}

In this qualitative research, the semi-structured interview is applied. According to Dornyie (2007), "semi-structure interview" type which suggests compromise between the two extremes is the most conducted interview.

The interviews were conducted in Persian which is the mother tongue of the interviewees so that they could express their opinions without the anxiety speaking in English might have provoked in them. In order to gather data for this study, all the interviews were recorded by voice recorder, since note taking was not adequate and also it interrupted the interviewer. Before commencing the recording, some points were explained to all interviewees. First, the reason for recording voices was explained, since some of the people do not like to be recorded. Afterward, the reason for carrying out interview was justified, as according to Dörnyei (2007), in order to motivate the interviewee to reply in detail and openly, the purpose of the questions must be conceived by them.

The main questions which were asked in the interviews are as follows:

(1) What kind of identity does this book attempt to boost? National identity or global identity?

(2) If a student just studies Prospect series, can he or she communicate effectively with foreign people?

(3) How much the intercultural communicative competence issues are dealt with in this book?

(4) What is the cultural policy of Prospect 1 ? 
(5) Is there anything else you would like to add regarding the cultural matters of Prospect 1 ?

During conducting interviews some probes were applied. According to Dörnyei (2007), probes enhance the richness and depth of the answers. They may include detail-oriented questions in order to clarify that response. Therefore, in case any of the responses needed clarification, a prominent word uttered by the respondent was taken and asked to elaborate. For instance, in response to my final closing question, Ms. Mobarrez, one of the seventh grade English teachers in Mashhad, said:

"I believe we should teach cultures to our students separately".

The word "separately" seemed vague. So I asked:

"You have used the word 'separately'. What exactly do you mean by that?"

\section{Data Analysis}

Since the data of this qualitative research consisted of recorded files, the first phase of the analytical process was to transcribe the data and turn the recordings into transcripts. The next phase was second-level coding in which all the respondents' accounts were studied again and all the codes that had been distinguished were listed. Some of the categories were similar; therefore, they were clustered together under a wider label. Based on different teachers' explanations and expositions about questions, similar or common opinions were identified. The statements were categorized to different codes and the percentage of each code was calculated.

\section{Results}

As the interviews were carried out with 30 high schools English teachers from Mashhad and some other cities, they were coded and the percentage of each code was calculated (see Table 1).

Table 1

\begin{tabular}{lll}
\multicolumn{2}{l}{ Identified Result Codes } & Percentage \\
\hline No. & Code & $80 \%$ \\
\hline 1 & National identity & $10 \%$ \\
2 & International identity & $10 \%$ \\
3 & Both national and international identity & $33.3 \%$ \\
4 & Able to communicate with foreign people effectively & $40 \%$ \\
5 & Not able to communicate with foreign people effectively & $26.7 \%$ \\
6 & To some extent able to communicate with foreign people effectively & $100 \%$ \\
7 & Not accentuating intercultural issues in the book & $83.5 \%$ \\
8 & Iranian/Islamic policy and teaching Iranian cultures via English language & $11.11 \%$ \\
9 & No opinion on cultural policy & $5.5 \%$ \\
\hline
\end{tabular}

As shown in Figure 1, in response to the first question of the interview, 80 percents of the teachers believed that the national identity is boosted in this book. They mainly referred to this point that there are some words and pictures which are just related to Iranian people and cultures and it is not useful for students to use them in a foreign context. They also pointed out that the characters are all Iranian since their names and most of their clothes - like Chador and Manteau - are all Iranian in this book. Also the book mentions some national heroes and political figures that students already know and they are all familiar with. For instance, a teacher maintained that the book is inculcating national identity rather than an international one with a focus on the Iranian context. All the names of the participants in the conversations of the book are also Iranian: Ali, Omid, 
and Reza. It would be much better to use foreign names, so that the students get familiar with the names of other countries. Another English teacher from Khoozestan commented, "Unfortunately the book does not give international identity to our students. These are all true and deserve appreciation that they have applied CLT approach for writing the new book and this helps both the teacher and learner to be free in performance and also their goal was culture-building practices in our country, but if they had written the book from International point of view, it would have been much better. Because in this way they could have had effective and global communication, in case they go to other countries such as France, China, and Netherlands and so on. Therefore, they know that they should not greet in Iranian way and their greetings are much better to be convergent to that of that country".

Ten percent of the teachers believed that book indicates an international identity not a national one. One of them remarked that international identity was the aim of the authors to be highlighted. There are only two or three words such as chador and manteau which are Iranian. But since the language is English then, the Iranian identity is not conveyed. Even in the level of greetings and basic conversations, the Iranians make many Ta'arofs. This is their culture. But you cannot see any trace of Ta'arof throughout the book.

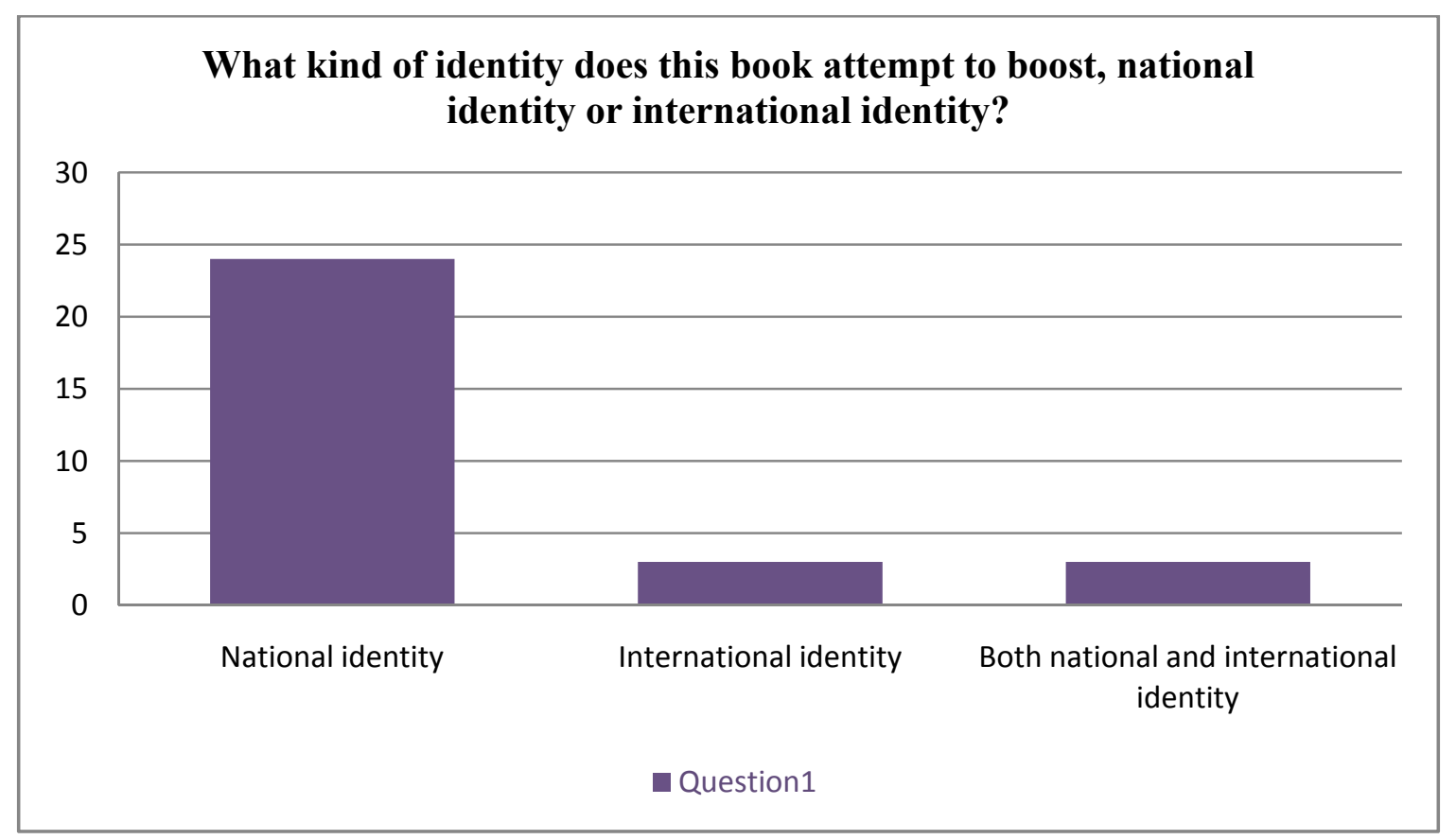

Figure 1. Question 1.

The second question posed to the participants was about the effectiveness of the type of communication which the students might establish in future with foreign people. As demonstrated in Table, three types of response were given regarding this point. The majority of teachers believed that learners will not be able to communicate effectively and their communication will encounter some troubles. For instance, one replied: "Actually students will not be able to communicate successfully with foreigners because the book is developed based on teaching English as a foreign language not second language. Based on this concept; thus, communication with foreigners via this book is not possible".

Another English teacher from Bojnord also remarked that this is not going to happen. She continued: "We are teaching our culture in English. So, it is crystal clear that our students cannot communicate properly with 
foreign people, since they are not familiar with their customs and cultures. They only learn Iranian culture in this book and that's all. Maybe they can only communicate with the basic greetings, but they might not be able to maintain their communication".

About 30 percent of the participants maintained that the book will enable learners to communicate successfully with foreigners. One of them reported: "The reason that I say this successful communication is possible is that reading any kind of English text or book helps improving English, even the materials published which might not be consistent with the latest trends of research in the field. That is, reading any English book is not fruitless. Therefore, I believe students can learn foreign culture from this specific book as well. I also believe learners can learn foreign culture just partly by studying their course book. The great proportion of achieving this end is by living in that specific context. Hence, we cannot expect a lot from school course books". Another teacher reported that learners can learn to communicate properly in anyway because conversations are the cornerstones of this book. So this is not something far-fetched. Around 25 percent of the participants claimed that this kind of communication is partially feasible.

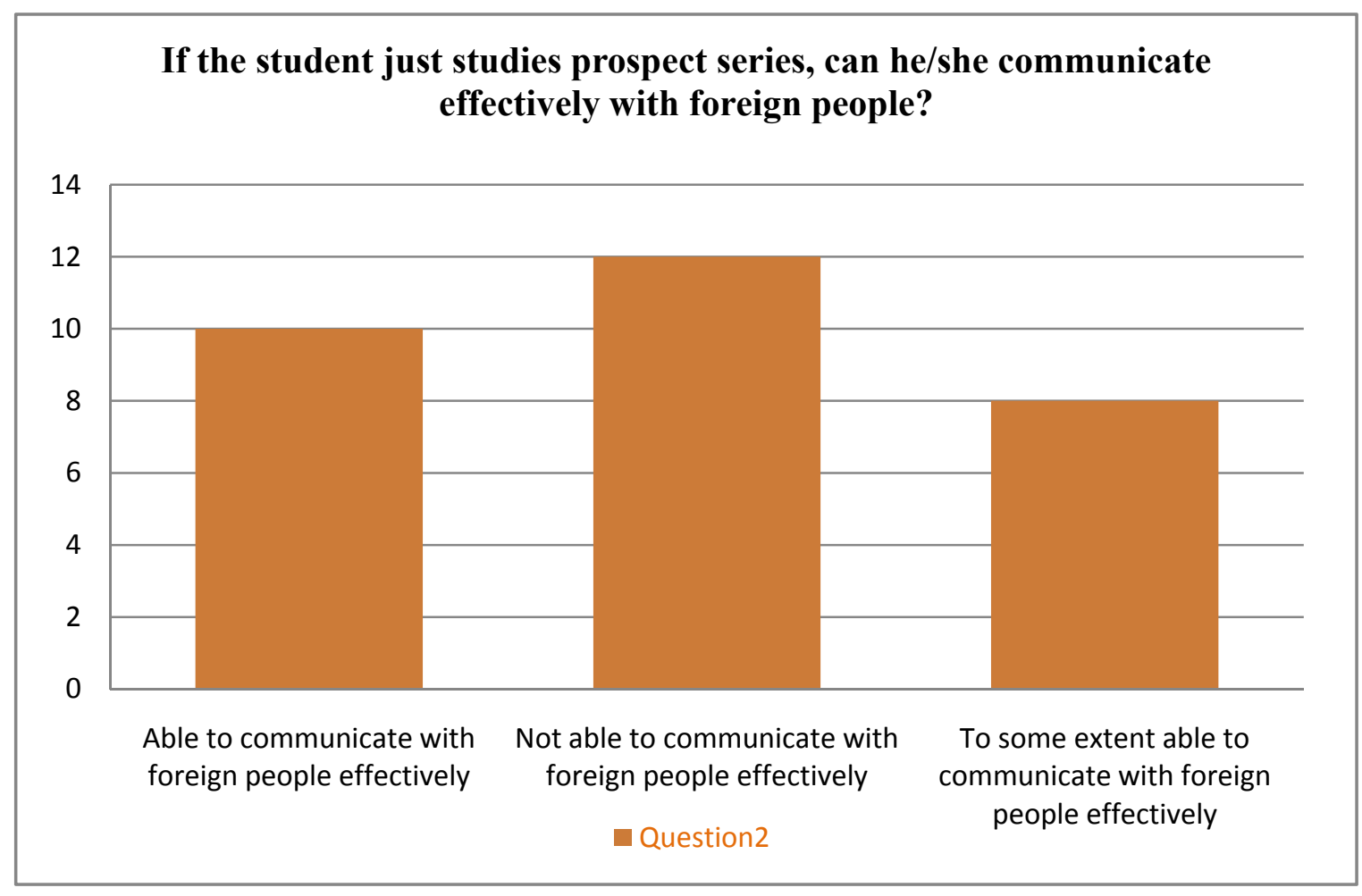

Figure 2. Question 2.

The third question posed to the teachers addressed the matter of intercultural communication issues. Almost all of the participants contended intercultural communication competence is not accentuated in Prospect 1 . 


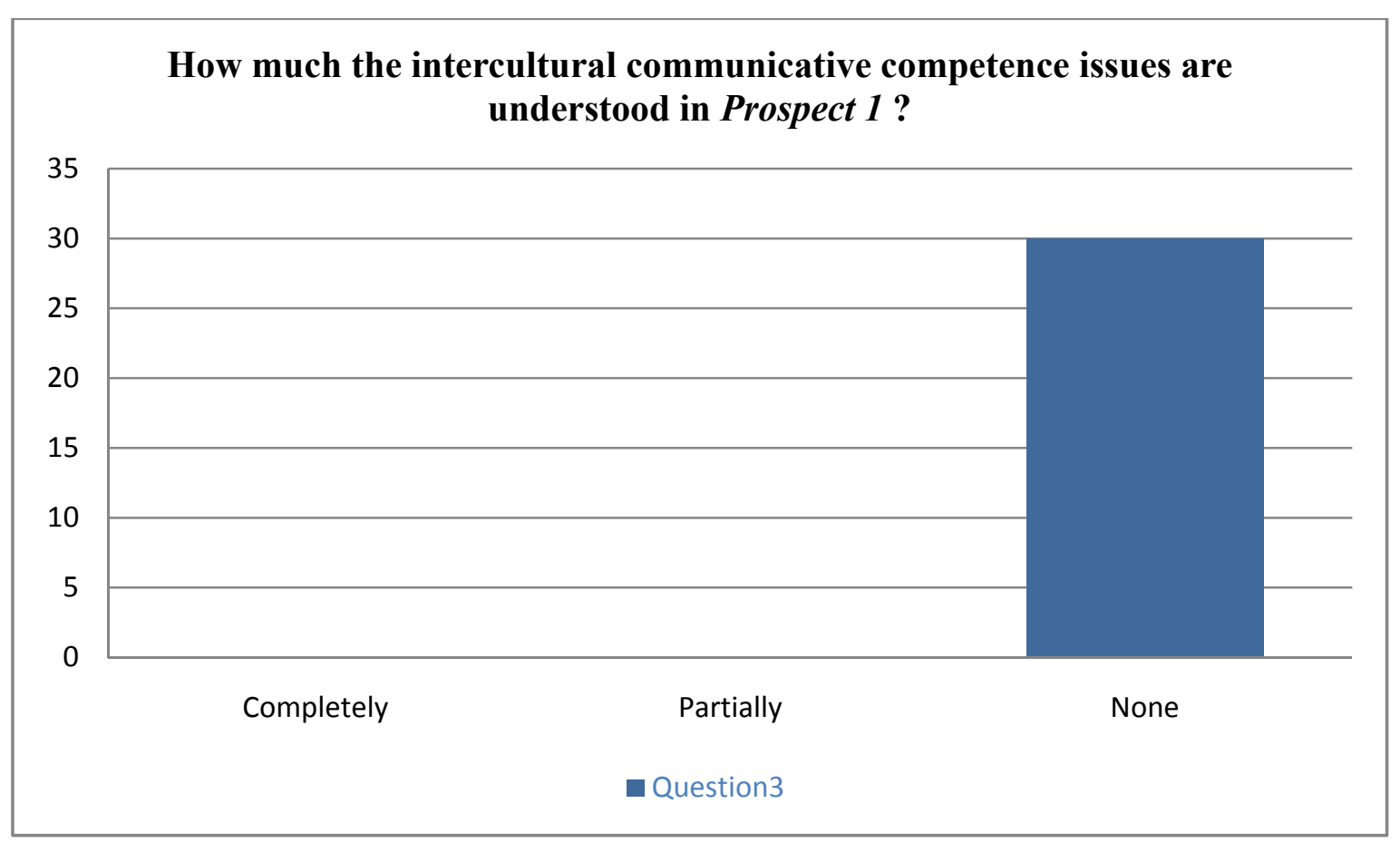

Figure 3. Question 3.

Finally the last main question was related to teacher's opinions about the cultural policy latent in Prospect 1. In answering this question, 36 different opinions were elicited from 30 participants ranging from firm opinions such as implementing Islamic-Iranian policy in the official English textbook to doubtful opinions of not following any specific cultural policy.

About 80 percent of the comments indicated that the cultural policy of Prospect was to implement the Islamic-Iranian beliefs and lifestyles and to localize this foreign language by teaching Iranian cultures and customs via English language. Among these comments, one teacher also believed that the other cultural policy implemented in the newly-written book was to lessen the role of English language for the learners, since the new series is much more demanding than the former textbooks and the time for teaching it in schools has not been increased and the teachers encounter shortage of time and enough practices cannot be done.

10 percent of the comments indicated that teachers do not have any idea about the cultural policy of the book and about 5 percents of the comments showed that some of the participants believe that the book does not follow any specific policy. 


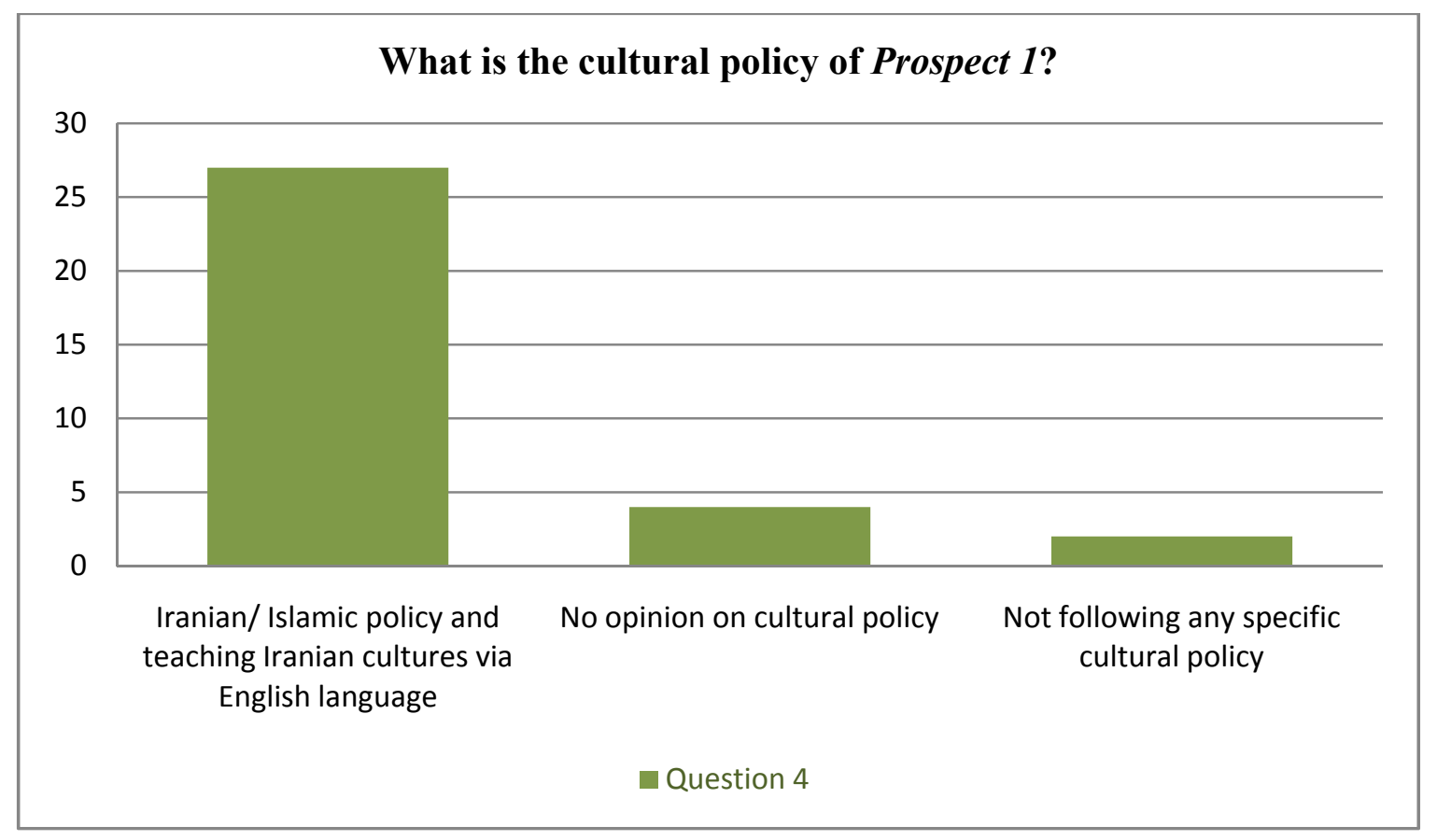

Figure 4. Question 4.

\section{Discussion}

As reported briefly before, 10 codes were identified after carrying out the interviews with the participants. The first three codes are related to the first question of the interview, talking on the concept of national identity versus global identity. The highest percentage of this issue belongs to teachers believing the national identity is highlighted in the book. Today, English as a lingua franca provides the chance for people throughout the world to communicate with each other. Though people of different nations have their own languages and speak diversely even when they learn English, their speaking skill is disparate, they can establish communication by means of English. This unity in diversity is possible through English as a Lingua Franca. In addition, today the ultimate goal of English learning is not achieving native-like proficiency in English language. The language learning goals of many current users of English are more limited than the goals of those who learn English as a result of speaker migration. Achieving native speaker competence is also pointless, since it will do little to contribute to a better understanding of the various ways English is used within multilingual contexts for international purposes. Moreover, it can be problematic because the so-called native speaker is not a homogeneous group, that is, individuals within the same country can have different standards of pragmatic appropriateness. There are still several reasons that the concept of native speaking proficiency is to some extent on the shelf. English is viewed as an additional language and as a language for international communication. Hence, teaching international language is underlined in the era of globalization. As pointed out in the literature review, the matter of culture is irresolvable from language learning and as many scholars have observed, English is rapidly losing its national cultural base and is becoming associated with a global culture (Dörnyei, 2005 , p. 104). Thus, alongside learning international language, international or global culture should be taught in order to become cognizant of various customs and use them in appropriate situations. This should be the concern of English textbooks throughout the world. In Iran, the most important way of learning English is via 
textbooks. Even in the technology era, different tools such as Internet, CDs, and so forth cannot take pivotal role of the books. We can still see that our students are book dependent and are looking for various books. This dependence is much more shown in schools and our official books. As mentioned previously, the newly written book Prospect 1, unlike great expectations raised, still cannot satisfy some of student's needs. From the very first sight, it can be construed that the aim of the authors was to write the book from an ecological perspective encompassing local cultures by means of English language. $80 \%$ of the teachers explicated various local issues mentioned in the book, such as Iranian names, Iranian-Islamic type of clothing, local foods, and so forth. It can be perceived that there is a fallacy in forming this ecological perspective which has taken the form of a radical localization. There is no place for international cultures and; as a consequence, international identity in their ecological views. Our local lifestyles and also national identity should be highlighted by Persian language as it has been already done and our students are already aware of these matters explicitly or implicitly. Human behavior is meaningful only when viewed in the socio-cultural context in which it occurs (Segall, 1979, as cited in Segal, Lonnerand, \& Berry, 1998, p. 1). That is, when Persian language does suffice in Iranian socio-cultural context to meet the daily needs, then there is no requirement to learn and use English language in such an Iranian context. Therefore, based on the evidences in the book and the interviews, we can arrive at conclusion that the interpretation of the ecological perspective in our country is not accurate since we are not supposed to survive and protect Iranian cultures and lifestyles by using a foreign device or foreign language. The appropriate ecological perspective should make connection to the globalization trend so that the interaction to people of other nations, which is today the main purpose of English learning, can be greatly facilitated. Considering only the aspect of local context is not sufficient. Crucial steps should be made towards welcoming unity in diversity like those take place in the official English learning textbooks in Iraq which like ours, is a Middle East country. Iraq Opportunities upholds cultural values both at the national and international scale unlike ours.

In addition, as mentioned in the literature review, a similar study was carried out on Chinese official English textbooks and the results revealed that in a country of expanding circle like China, the material developers observed the globalization elements such as texts about cultures other than those of traditional inner-circle cultures for secondary schools English textbooks. Additionally, cross-cultural perspectives are represented in their English textbooks. Besides, texts raising learners' awareness of world Englishes and local functionalities of English are included in the textbooks. Comparing Iranian official English textbook with Chinese English course books raises our expectation to include these elements in the new Iranian course books as well.

The second question of the interview regarding effective and successful communication includes the next three codes of the results. The majority of the responses belong to the teachers who believed students who only study Prospect will not be able to communicate successfully with foreign people.

Lantolf and Thorne (2005) explained the socio-cultural theory of Vygotsky that language is the most significant socio-cultural tool, which has a great power in mediating the learning (p. 1). Hence, based on this theory of Vygotsky, it can be concluded that in Iran language as a mediator is limited to the context of our own country and its mediating capacity is not used to increase the potential of Iranian learners in terms of their communication with the broad community of English language.

Moreover, based on Bernstein's Deficit Theory (1966), we can conclude that teaching only local cultures 
provides Iranian learners with a restricted code since the materials in the book are all context-dependent and particularistic. In other words, communication with foreigners require background information and shared knowledge but this is restricted since the Iranian learners studying English with Prospect are not provided with this shared knowledge; they mainly learn English with a focus on Iranian manners and interact based on Iranian context of the book. If the book had covered elaborated code of language, then we could have claimed that the book has used the great capacity of the world mediator which is English language to broaden their communicative competence. Furthermore, it would have helped students to get prepared for the life and survive in the globalization era. According to Sen (2006, as cited in Dervin, 2010), people are miniaturized as they are reduced to one single identity, that of a culture which is, in turn, reduced to national and geographical boundaries (p. 3). Thus, this limitation does not contribute to a global citizenship and; therefore, not to have a global identity via English language. Global citizen is defined as a person who constructs an identity within a global community, above his or her identity as a citizen of a particular nation or place. The idea is that one's identity transcends geography or political borders and that the planetary human community is interdependent. This does not mean such a person denounces their nationality or other more local identities, but such identities are given second place to their membership in a global community.

The other consequence of this limitation is linguistic imperialism which is felt as a covert threat. We have always believed that if non-Iranian information is included in our official books the linguistic imperialism occurs, whereas this is considered wrong, for this view is in fact regarded as linguistic hospitality and not linguistic imperialism anymore. Linguistic hospitality aims at making peaceful coexistence between languages and though they are dissimilar, it agrees these diversities and makes languages able not to fall under influence of the other one. Rather than being seen as a threat, however, English should be seen not only as a means for countries to join the global community and compete in the international arena, but a means of making their national identity and culture known to the rest of the world. Hence, through linguistic hospitality, it is possible to introduce and share Iranian cultures to the other nations. In fact, the real linguistic imperialism happens in current situation of our country by using a foreign tool such as English language to teach our cultures and lifestyles in the Iranian context, where teaching these information is possible by our own mother tongue. The purpose of using English in globalization era is to facilitate global interaction. Therefore, we should be cautious about this covert threat and instead embrace linguistic hospitality and discard such a resistance so that we can be cognizant of foreign cultures and customs or; in other words, waive linguistic hostility.

Furthermore, by learning a foreign language, we aim at engaging in dialogue. Based on Bakhtin's Dialogism Theory (1929), to exist is to engage in dialogue. The other's response can change everything in one's own consciousness or perspective. A single consciousness separate from interaction with other consciousness is impossible. Consciousness is always a product of a responsive interaction and cannot exist in isolation. Thus, we can arrive at a conclusion that by introducing foreign cultures in our official textbooks, we can create the consciousness of our own cultures and lifestyles for our students. That is, they can understand much better the Iranian cultures by comparing them to the foreigners' cultures and regarding the value of ours. In this way, we can prevent linguistic imperialism and encourage them to respect and put value to Iranians' customs and lifestyles.

\section{Conclusion}

This study was an attempt to show that in globalization era, English language plays a key role as a 
mediator and is an international language through which, communication to people of different nations is possible. Thus, learning an international language without its culture is not sufficient in order to have effective communication with others. In addition, as the significance and necessity of acquiring intercultural communicative competence was discussed, learning the home culture and the target culture do not suffice and it should be attempted to make all English learners to be cognizant of various lifestyles and cultures through books so that they will not encounter misunderstandings or embarrassments in their communication with the broad community of practice of English language. Based on the findings of this study, the cultural dimensions of English language learning policy of Prospect 1 is teaching Islamic-Iranian culture and disregarding intercultural communicative competence issues in the book.

However, the present study was conducted with the aims of exploring English language learning policy in light of globalization and culture based on Prospect 1. The material being studied is only the first book of the Prospect series and the rest, due to the newness of the series, were not published or taught thoroughly. Therefore, in order to complement the findings of the present study, similar studies are critically needed for the other books of Prospect series, such as Prospect 2, which is being taught now for the first year and the rest which are going to be taught in the following years.

Moreover, the participants of the research were limited to the teachers of ministry of education and only the teachers of Mashhad and some cities of Khorasan province and a teacher from Khoozestan. Thus, it is recommended to expand the range of interviewees and include first, the authors of the books and second, teachers of ministry of education of various cities of Iran. The other suggestion is to conduct a further study to provide or design various tasks to improve and boost the intercultural communicative competence of the students. Furthermore, since Iranian English learners are not limited to the official textbooks and they mostly participate in English language institutes, it is strongly recommended to carry out a similar study on these non-official English textbooks which are being taught to our students and observe whether these various books cover the intercultural communicative competence or not. Besides exploring the intercultural communicative competence of non-official English textbooks in Iran, it is also recommended to explore the matter of linguistic imperialism of these various English textbooks of the institutes. The other recommendation is to conduct a thorough study in order to compare language learning policy of several countries of expanding circles with that of Iran based on their official English textbooks.

\section{References}

Aouina, H. (2013). Globalisation and language policy in Tunisia: Shifts in domains of use and linguistic attitudes (Unpublished Ph.D. dissertation, University of West of England).

Atherton, J. (2002). Language codes. Retrieved from http://www.doceo.co.uk/language_codes.htm

Baker, C. (2011). Foundations of bilingual education and bilingualism (Vol. 79). Philadelphia, PA: Multilingual Matters.

Bhatt, R. M. (2008). In other words: Language mixing, identity representations, and third space1. Journal of Sociolinguistics, 12(2), 177-200.

Brutt-Griffler, J. (1998). The development of English as an international language: A theory of world language (Doctoral dissertation, The Ohio State University).

Byram, M. (1992). Language and culture learning for European citizenship. Language and Education, 6(2-4), 165-176.

Creese, A., Martin, P., \& Hornberger, N. H. (2008). Ecology of language: Encyclopedia of language and education (Vol. 9). USA: Springer.

Crystal, D. (2003). English as a global language. Stuttgart, Germany: Ernst Klett Sprachen.

Deckert, S. K., \& Vickers, C. H. (2011). An introduction to sociolinguistics: Society and identity. London: Continuums.

Dervin, F. (2010). Assessing intercultural competence in language learning and teaching: A critical review of current efforts. In F. 
Dervin and E. Suomela-Salmi (Eds.), New approaches to assessment in higher education (pp. 157-173). Bern: Peter Lang.

Dörnyei, Z. (2005). The psychology of the language learner: Individual differences in second language acquisition. Mahwah, NJ: Lawrence Erlbaum.

Dörnyei, Z. (2007). Research methods in applied linguistics: Quantitative, qualitative, and mixed methodologies. Oxford: Oxford University Press.

Freeman, D. (2002). The hidden side of the work: Teacher knowledge and learning to teach. Language Teaching, $35(1), 13$.

Hung, T. T. N. (2009). How the global spread of English can enrich rather than engulf our culture and identity. HKBU Papers in Applied Language Studies, 13, 41-53.

Jamshidifar, S. (2011). English language policy and planning in Iran (Doctor of Philosophy, University of Southampto).

Jenkins, J. (2006). Points of view and blind spots: ELF and SLA. International Journal of Applied Linguistics, 16(2), $137-162$.

Jenkins, J. (2009). English as a lingua franca: Interpretations and attitudes. World Englishes, 28(2), 200-207.

Kachru, B. B. (1992). Models for non-native Englishes. The Other Tongue: English Across Cultures, 2, 48-74.

Kirkgöz, Y. (2009). Globalization and English language policy in Turkey. Educational Policy, 23(5), 22.

Kramsch, C. (2005). Foreign languages between knowledge and power. Applied Linguistics, 26(4), 545-567.

Kramsch, C. J. (2009). The multilingual subject: What foreign language learners say about their experience and why it matters. Oxford: Oxford University Press.

Kramsch, C., \& Vork Steffensen, S. (2008). Ecological perspectives on second language acquisition and socialization. In N. Hornberger (Ed.), Encyclopedia of language and education (pp. 2595-2606). US: Springer.

Kaur, P. (2014). Accent attitudes: Reactions to English as a lingua franca. Procedia-Social and Behavioral Sciences, $134,3-12$.

Lantolf, J. P. (2006). Sociocultural theory and L2: State of the art. Studies in Second Language Acquisition, 28(1), 67-109.

Lin, H. Y. (2013). Critical perspectives on global English: A study of their implications. Intergrams, 13(2), 24.

Ljungdahl, L. (2004). The English language and linguistic imperialism: The Trojan Horse? In European, Mediterranean and Middle Eastern Conference on Information Systems. Common Ground Publishing.

Matsuda, A. (2012). Teaching materials in EIL. Principles and Practices for Teaching English as an International Language, 168-185.

Mckay, S. L. (2003). Toward an appropriate EIL pedagogy: Re-examining common ELT assumptions. International Journal of Applied Linguistics, 13(1), 22.

Mollin, S. (2006). English as a lingua franca: A new variety in the new expanding circle? Nordic Journal of English Studies, 5(2), 18.

Mahadi, T. S. T., \& Jafari, S. M. (2012). Motivation, its types, and its impacts in language learning. International Journal of Business and Social Sciences, 3(24).

Nieto, S. (2010). Language, culture, and teaching: Critical perspectives. New York and London: Routledge.

Nieto, S. (2010). Language, culture, and teaching (2nd ed.). Taylor \& Francis e-Library: Routledge.

Paivandi, S. (2012). Education in the Islamic Republic of Iran and perspectives on democratic reforms. London: The Legatum Institute.

Pennycook, A. (1997). Critical applied linguistics and language education. In R. Wodak and D. Corson (Eds.), Encyclopedia of language and education (Vol. 1, pp. 23-31). Dordrecht, the Netherlands: Kluwer.

Phillipson, R. (1997). The politics of English language teaching. In R. W. A. D. Corson (Ed.), Encyclopedia of language and education: Language Policy and Political Issues in Education (Vol. 1, pp. 201-209). Dordrecht, the Netherlands: Kluwer.

Phillipson, R. (1996). Linguistic imperialism: African perspectives. ELT Journal, 50(2), 160-167.

Phillipson, R. (2009). Linguistic imperialism continued. UK: Routledge.

Phillipson, R., \& Skutnabb-Kangas, T. (1996). English only worldwide or language ecology? TESOL Quarterly, 429-452.

Pishghadam, R. (2011). Introducing applied ELT as a new approach in second/foreign language studies. The Iranian EFL Journal, $7(2), 8-14$.

Quirk, R. (1985) The English language in a global context. In R. Quirk and H. G. Widdowson (Eds.), English in the world: Teaching and learning the language and literatures (pp. 1-6). Cambridge: Cambridge University Press.

Sapir, J. D. (1971). West Atlantic: An inventory of the languages, their noun class systems and consonant alternation. Current Trends in Linguistics, 7(1), 43-112.

Segall, M. H., Lonner, W. J., \& Berry, J. W. (1998). Cross-cultural psychology as a scholarly discipline: On the flowering of culture in behavioral research. American Psychologist, 53, 1101-1110.

Sen, A. (2006). Identity and violence: The illusion of destiny. New York: Norton Adult Education Quarterly.

Sharifian, F. (Ed.). (2009). English as an international language: Perspectives and pedagogical issues (Vol. 11). Bristol, UK: 
Multilingual Matters.

Sifakis, N. C. (2004). Teaching EIL—Teaching international or intercultural English? What teachers should know. System, 32(2), 14.

Skutnabb-Kangas, T., \& Phillipson, R. (2011). Language ecology. In J. O. Östman and J. Verschueren (Eds.), Handbook of Pragmatics (pp. 1-25). Amsterdam \& Philadelphia: John Benjamins.

Skutnabb-Kangas, T., \& Phillipson, R., (2001). Language ecology. In J. Verschueren, J. O. Östman, J. Blommaert, and C. Bulcaen (Eds), Handbook of pragmatics (pp. 1-18). Amsterdam \& Philadelphia: John Benjamins.

Sowden, C. (2007). Culture and the "good teacher" in the English Language classroom. ELT Journal, 61(4), 7.

Stern, H. H. (1992). Issues and options in language teaching. Oxford University Press.

Sumner, W. G. (1906). Folkways: A study of the sociological importance of usages, manners, customs, mores, and morals. Boston: Ginn and Co..

Sun, W. (2013). How to cultivate intercultural communication competence of non-English major students. Theory and Practice in Language Studies, 3(12), 5.

Tsui, A. B., \& Tollefson, J. W. (2007). Language policy, culture, and identity in Asian contexts (pp. 1-283). Mahwah, NJ: Lawrence Erlbaum Associates.

Valdes, J. (1990). The inevitability of teaching and learning culture in a foreign language course. In B. Harrison (Ed.), Culture and the language classroom (pp. 20-30). London: Modern English Publications.

Wendel, J. N. (2005). Notes on the Ecology of Language. Bunkyo Gakuin University Academic Journal, 5, 51-76.

Wiertlewska, J. (2011). Ecolinguistic approach to foreign language teaching on the example of English. Poznań: Adam Mickiewicz University Press.

Xu, Z. (2013). Globalization, culture and ELT materials: A focus on China. Multilingual Education, 3(1), 1-19. 